Acta Theriologica 44 (4): 353-362, 1999.

PL ISSN 0001-7051

\title{
Estimation of fat sand rat Psammomys obesus abundance by using surface indices
}

\author{
Elisabeth FICHET-CALVET*, Iadh JOMAA, Patrick GIRAUDOUX \\ and Richard W. ASHFORD
}

Fichet-Calvet E., Jomaa I., Giraudoux P. and Ashford R. W. 1999. Estimation of fat sand rat Psammomys obesus abundance by using surface indices. Acta Theriologica 44: 353-362.

The fat sand rat Psammomys obesus Cretzschmar, 1828 is an important reservoir host for the human disease, cutaneous leishmaniasis. To develop a method for monitoring changes in the population density of this rodent over large areas, fragments of food, faeces, urine marks, and earth mounds at the burrow entrance were evaluated as indicators of abundance. The results were compared with population density measured simultaneously by trapping. Through the year as a whole, urine marks correlate poorly with abundance, but the three other indicators correlate well. A correlation coefficient of 0.74 is achieved with food fragments and faeces combined. The correlation is best during the wet season and poorer in dry conditions. The value of this indirect population index is discussed in relation to climatic conditions. Details are proposed for the establishment of a monitoring system for $P$. obesus populations in time and space.

Liverpool School of Tropical Medicine, Pembroke Place, Liverpool L3 5QA, UK (EF-C, RWA); Laboratoire d'Epidémiologie et d'Ecologie Parasitaire, Institut Pasteur de Tunis, BP 74, 1002 Tunis Belvédère, Tunisie (IJ); Laboratoire de Biologie et d'Ecophysiologie, Place Leclerc, Université de Franche-Comté, 25030 Besançon Cedex, France (PG)

Key words: Psammomys obesus, Rodentia, abundance index, presence indices, weather conditions

\section{Introduction}

Landscape features are generally considered to have important effects on the population dynamics of small mammals (Teivanen 1979, Delattre et al. 1992, Lidicker 1995, Steen et al. 1996). Studies of such effects are complicated by the problem of estimating populations over wide areas, where mark-release, trapping effort and similar methods suitable for small-scale studies are impractical on a larger scale. Large-scale monitoring of populations is, however, desirable for the prediction of surges of agricultural pests (Giraudoux et al. 1997), or of medically important rodents.

\footnotetext{
* Present address: Lab. Ecoéthologie des rongeurs, ISEM - CC 64 - Univ. Montpellier II, Place Eugène Bataillon, F-34095 Montpellier Cedex 05, France, e-mail: calvet@isem.univ-montp2.fr
} 
The fat sand rat Psammomys obesus Cretzschmar, 1828 is the main reservoir host throughout North Africa and West Asia, of Leishmania major, which causes zoonotic cutaneous leishmaniasis or oriental sore in humans (Ashford et al. 1977, Ben Ismail et al. 1987, 1989, Rioux et al. 1990, 1992). Epidemics of this disease appear to be related either to high densities of the rodent close to human habitation, during population outbreaks, or to the penetration of people into normally sparsely inhabited areas. A method is required to monitor sand rat population density and distribution, for the purpose of epidemiological surveillance, which is cheap, easy and reliable. Similar methods have been developed for monitoring vole (Microtus, Arvicola) populations, using surface indicators of the presence of rodents such as damaged vegetation, faeces, diggings etc. Studies using these methods have shown that the reduced accuracy of indirect methods is compensated by the ease of obtaining data over wide areas and long time periods: Lidicker and Anderson (1962) for the Californian vole Microtus californicus, Liro (1974), Mackin-Rogalska et al. (1986), Delattre et al. (1990, 1996) for the common vole Microtus arvalis, Teivanen (1979) for the bank vole Clethrionomys glareolus, Wang (1993) for the Mediterranean pine vole Pitymys duodecimcostatus, Giraudoux et al. (1995) for the fossorial form of the water vole Arvicola terrestris scherman.

$P$. obesus is active by day, and lives in relatively wet parts of arid areas such as the edges of wadis or salt pans, with halophilic vegetation. It is exclusively vegetarian, eating mainly the leaves and stems of succulents of the family Chaenopodiaceae (saltbush, glasswort, samphire etc), which are rich in water and salts (Kam and Degen 1989, Zaime and Gautier 1989). P. obesus constructs its burrow, 0.5 to $1 \mathrm{~m}$ deep, under the saltbushes. For an individual burrow, the number of entrances may vary from five to fifteen (Petter 1961, pers. obs.). The presence of an animal in a burrow may be recognised by any of four indicators at the entrance: freshly cut fragments of saltbush, faeces, marks of blackened urine, or freshly dug earth, sometimes mixed with nest material or debris, forming a raised platform at the burrow entrance.

The study described here was designed to find which of the above indicators, alone or in combination, correlates best with abundance, and to find the season or weather conditions when abundance can most accurately be estimated.

\section{Study area}

The study was carried out $40 \mathrm{~km}$ south of Sidi Bouzid, in Tunisia, at the edge of a "sebkha" or salt pan, Garat an Njila ( $35^{\circ} 46^{\prime} \mathrm{N}, 9^{\circ} 36^{\prime} \mathrm{E}$, altitude $280 \mathrm{~m}$ ). The site, which measures 100 ha is bordered to the east by Jebel Gouleb $(738 \mathrm{~m}$ ) and to the west by a steppe of succulent halophilic vegetation (Le Houerou and Le Floc'h 1995). The site is divided by raised dykes built for flood control, and by ploughed areas with wheat. Natural vegetation is restricted to the raised dykes and to the divisions between the fields, and is composed predominantly of Chaenopodiaceae of the genera Salsola, Suaeda and Arthrocnemum, with occasional Atriplex sp. (Ozenda 1991, J. Mathez, pers. comm.). This represented the remains of the edge of the sebkha, heavily modified for agriculture. Rodents were sampled in the bands of natural vegetation, 1 to $2 \mathrm{~m}$ wide, separating the fields of wheat. 


\section{Material and methods}

\section{Data collection}

The work reported here was part of medical survey for cutaneous leishmaniasis, in which the counting of internal parasites required sacrifice of animals and consequently, removal trapping. The trap lines were placed in different locations at each session, so that no vegetation band was sampled more than once in a year. On 7 bimonthly occasions between July 1995 and August 1996 and on an additional one in January 1997, collapsible, mesh cage-traps, $10 \times 10 \times 30 \mathrm{~cm}$ were baited with freshly cut stems of succulent plants and set in lines. Nineteen trap lines varied between 60 and $280 \mathrm{~m}$ in length, and contained between 30 and 72 traps (Table 1). Each trap was located at burrow entrance. The rodent is very sedentary, only altering its home range over periods of several months (Petter 1961, Daly and Daly 1975). If a burrow is constructed beneath a salt-bush, the animal moves hardly at all, and those with burrows further from plants move only a few metres, returning frequently to the burrow entrance with food which is eaten on the platform at the entrance.

The traps were grouped in $5 \mathrm{~m}$ intervals, with between 0 and 7 traps per interval, depending on the number of burrow openings. Each $5 \mathrm{~m}$ interval was scored in terms of the four indicators and the number of animals captured in each three-day session. From dawn to dusk the traps were constantly guarded against disturbance and closed during the night; they were emptied at 2-hourly intervals during hot weather, and every three hours in colder periods.

Table 1. Number of lines, traps and captures per line and their length in $\mathrm{m}$ by month which are characterized in dry $(\mathrm{D})$ or wet $(\mathrm{W})$ period.

\begin{tabular}{lcccr}
\hline Month & Lines & Traps & Captures & Length \\
\hline July 1995 (D) & 1 & 30 & 3 & 65 \\
September 1995 (W) & 2 & 30 & 8 & 155 \\
November 1995 (W) & 2 & 30 & 3 & 70 \\
January 1996 (W) & & 30 & 10 & 140 \\
& 2 & 30 & 9 & 130 \\
March 1996 (W) & & 36 & 15 & 60 \\
& 2 & 36 & 10 & 65 \\
June 1996 (D) & & 36 & 16 & 80 \\
August 1996 (D) & 2 & 36 & 9 & 65 \\
& & 36 & 21 & 100 \\
& 3 & 36 & 10 & 200 \\
January 1997 (D) & & 72 & 20 & 280 \\
& & 36 & 11 & 185 \\
& 5 & 36 & 9 & 115 \\
& & 36 & 10 & 100 \\
& & 45 & 15 & 110 \\
& & 39 & 18 & 95 \\
& & 33 & 12 & 105 \\
\hline
\end{tabular}




\section{Data analysis}

Because the length of each line varied between 65 and $280 \mathrm{~m}$ and because the traps were unevenly distributed along the lines, an abundance index was used: the number of animals captured divided by the number of $5 \mathrm{~m}$ interval in each line. The mean of the abundance index for all lines in a given sampling session allows comparison among sessions and seasons. To standardize this index, it is converted to the number of $P$. obesus caught in $100 \mathrm{~m}$.

The biological peculiarities of $P$. obesus mentioned above preclude regular distance between traps, as these must be close to burrow entrances. The indicators were recorded as present or absent in each $5 \mathrm{~m}$ interval of trap line and were calculated as a proportion of intervals. The four indicators are fresh vegetation at a burrow entrance, at least one faecal pellet visible, at least one blackened urine mark and at least one freshly constructed platform at a burrow entrance. To avoid confusion with other partly herbivorous rodents such as Meriones shawi, only fresh green vegetation was taken into account. For example, the presence of wheat at the burrow entrance was not considered as an indicator.

A linear regression was calculated for each of the activity indicators against abundance. Stepwise multiple linear regressions were calculated to show the combination of activity indicators which most closely correlated with the relative abundance index.

Results were calculated separately for dry and wet periods. The wet period was defined on the basis of rainfall (over $40 \mathrm{~mm}$ in the previous month) and the number of rain days (more than 6 days in the previous month) which resulted in a green vegetation growth. January 1996 , with $93 \mathrm{~mm}$ rainfall and 26 rain days in the previous three months, was counted as a wet period, while January 1997, with only $21 \mathrm{~mm}$ rainfall and 4 rain days in the previous three months was counted as dry.

\section{Results}

\section{Trapping success}

Two hundred and thirty-five $P$. obesus were captured during 2094 trap-days.

A low but significantly $(p=0.001)$ positive correlation among the number of captures, the number of burrow openings, and the number of traps per $5 \mathrm{~m}$ interval was observed, which corresponds to $10.9 \%$ of the total variance (Fig. 1a). On the other hand, Fig. 1b shows that there was no correlation between the trapping success and the number of traps per $5 \mathrm{~m}$ interval. This means that the number of captures was dependent on the number of burrow openings, but with a high variability, and that trap efficiency was similar in any case. The abundance index observed was however not a simple function of trap density (eg the higher number of traps did not catched the higher number of animals).

\section{Variation in time}

The abundance index was greater between January and June, and declined in the summer months (Fig. 2). This pattern meets our knowledge about the seasonality of reproduction which leads to a population increase during winter and spring (Amirat et al. 1975, 1977, Fichet et al. 1999). This supports the idea that the abundance index can be used here as a reasonable reflection of the true variations of abundance. The activity indicators followed a similar trend. In July 1995 however, faeces and urine were relatively high, while the abundance was low. 


\section{Model for estimation of abundance from activity indicators}

Taking the year as a whole, "cut chenopods", "faeces" and "platforms" are significantly $(p=0.01)$ correlated with abundance, while "urine" is not. The formula which best describes the abundance of $P$. obesus is: $\mathrm{PO}=0.61 \mathrm{Ch}+0.42 \mathrm{Fa}$ $+0.02(r=0.74 ; p=0.0003)$, where "Ch" is the proportion of $5 \mathrm{~m}$ transects in which vegetation remains are seen at burrow entrances, and " $\mathrm{Fa}$ " is the proportion in which faeces are seen (Table 2, Fig. 3).
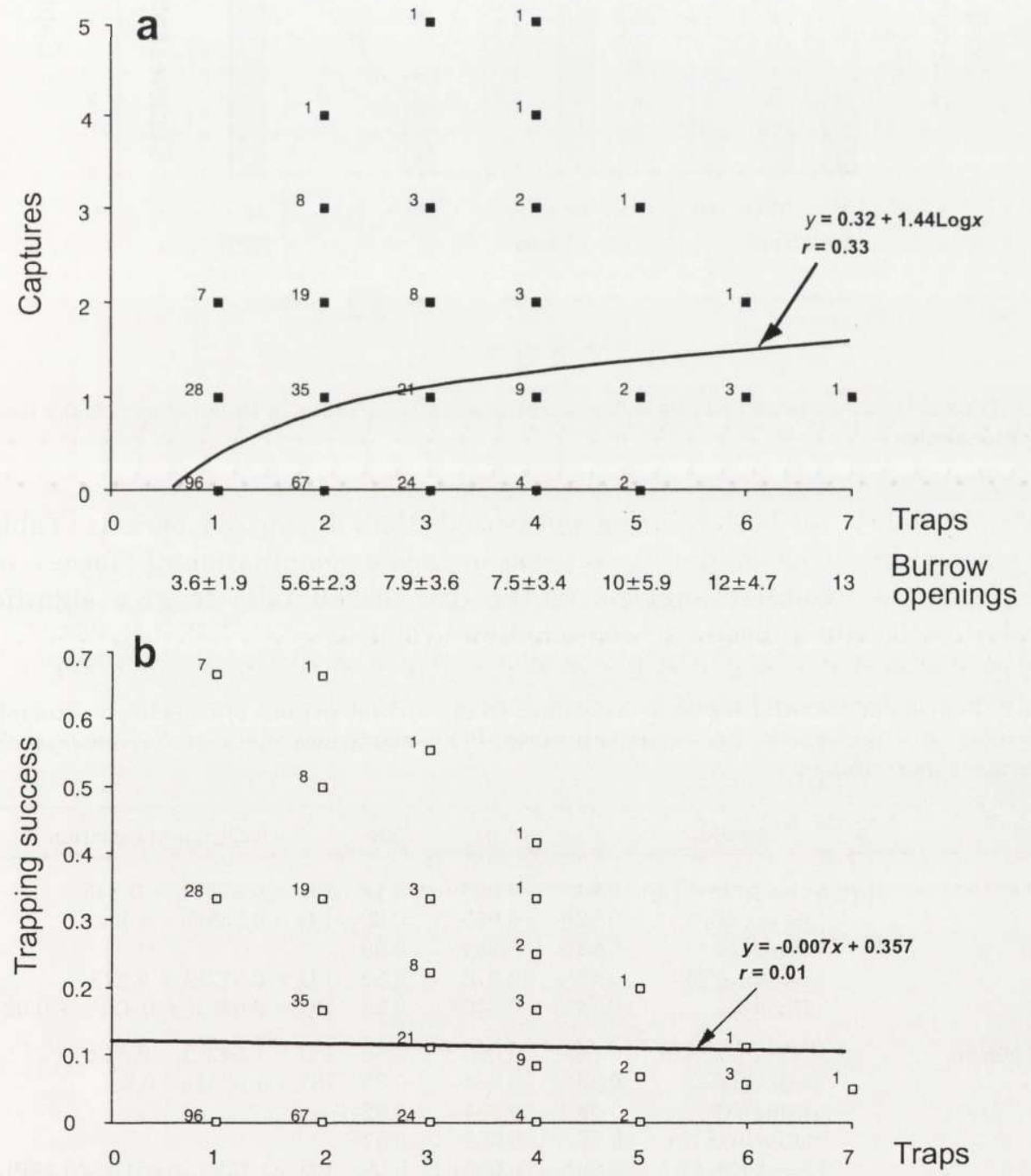

Fig. 1. Relations between the number of captures and the number of traps per $5 \mathrm{~m}$ interval (a) and between the trapping success and the number of traps per $5 \mathrm{~m}$ interval (b). Trapping success corresponds to the number of captures per trap-days. The numbers above the points correspond to the size of the samples. The mean number of burrow openings are mentionned for each number of traps. Total $n=349$ 


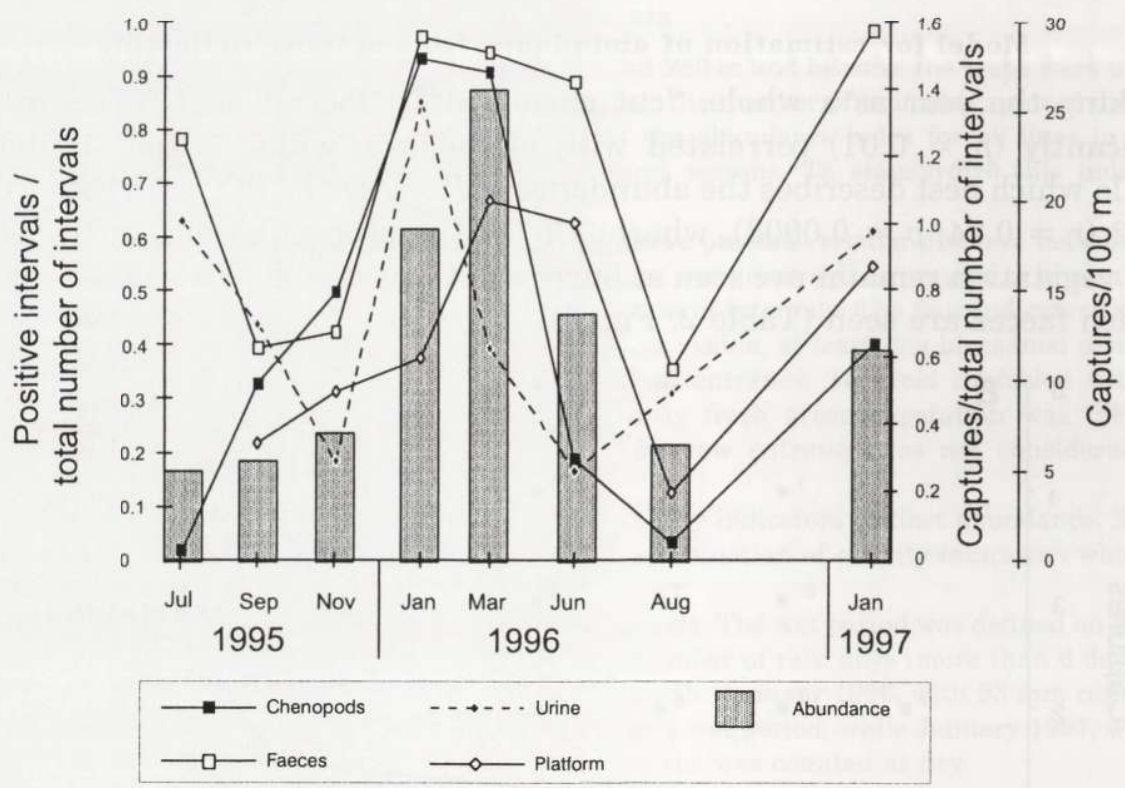

Fig. 2. The effect of season on activity indices and the abundance index in Psammomys obesus (see text for explanation).

Predictability was better during wet periods than during dry periods (Table 2). The optimal linear model during wet season used a combination of "faeces, urine and platforms". Similar analysis in the dry season fails to give significant correlation for any indicator or combination (Table 2).

Table 2. Simple and stepwise regressions obtained from different seasons of trapping. $r$ - correlation coefficient, $p$ - probability, SE - standard error, PO - abundance index of Psammomys obesus. * - remarkable correlation.

\begin{tabular}{|c|c|c|c|c|c|c|}
\hline Period & $n$ & Variable & $r$ & $p$ & SE & Regression equation \\
\hline \multirow[t]{5}{*}{ All over the year } & 19 & chenopods (Ch) & $0.64^{*}$ & 0.003 & 0.19 & $\mathrm{PO}=0.678 \mathrm{Ch}+0.346$ \\
\hline & & faeces $(\mathrm{Fa})$ & $0.62^{*}$ & 0.005 & 0.26 & $\mathrm{PO}=0.859 \mathrm{Fa}-0.002$ \\
\hline & & urine (Ur) & 0.22 & 0.364 & 0.30 & \\
\hline & & platform (Pl) & $0.58^{*}$ & 0.012 & 0.32 & $\mathrm{PO}=0.912 \mathrm{Pl}+0.273$ \\
\hline & & $\mathrm{Ch}+\mathrm{Fa}$ & $0.74^{*}$ & 0.0003 & 0.23 & $\mathrm{PO}=0.61 \mathrm{Ch}+0.42 \mathrm{Fa}+0.02$ \\
\hline \multirow[t]{5}{*}{ Wet period } & 8 & chenopods (Ch) & $0.86^{*}$ & 0.006 & 0.40 & $\mathrm{PO}=1.643 \mathrm{Ch}-0.342$ \\
\hline & & faeces $(\mathrm{Fa})$ & $0.88^{*}$ & 0.004 & 0.35 & $\mathrm{PO}=1.605 \mathrm{Fa}-0.33$ \\
\hline & & urine (Ur) & 0.08 & 0.854 & 0.62 & \\
\hline & & platform (Pl) & 0.75 & 0.032 & 0.57 & \\
\hline & & $\mathrm{Fa}+\mathrm{Ur}+\mathrm{Pl}$ & $0.99^{*}$ & 0.0001 & 0.04 & $\mathrm{PO}=1.75 \mathrm{Fa}-0.64 \mathrm{Ur}+0.48 \mathrm{Pl}-0.3$ \\
\hline \multirow[t]{4}{*}{ Dry period } & 11 & chenopods (Ch) & 0.46 & 0.160 & 0.23 & \\
\hline & & faeces $(\mathrm{Fa})$ & 0.56 & 0.070 & 0.24 & \\
\hline & & urine (Ur) & 0.43 & 0.187 & 0.25 & \\
\hline & & platform (Pl) & 0.56 & 0.093 & 0.27 & \\
\hline
\end{tabular}




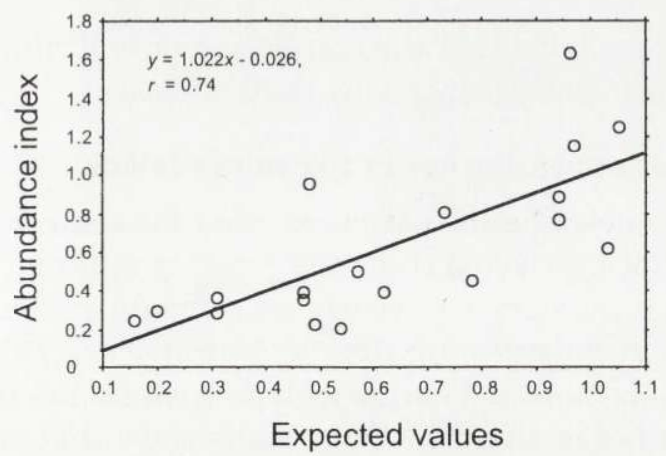

Fig. 3. Graph of the linear regression between abundance index and chenopod remains combined with faeces in the equation $y=0.61 x_{1}+0.42 x_{2}+0.02$ where $x_{1}$ - chenopods and $x_{2}$-faeces. $n=19$.

\section{Discussion}

\section{Activity indicators as measures of abundance}

The abundance index used here should certainly be re-evaluated in a more appropriate experimental design. However, this study conducted incidentally as part of a medical survey for cutaneous leishmaniasis, provides estimates on abundance variations which fully corroborates results obtained from reproduction analysis (Amirat et al. 1975, 1977, Fichet-Calvet et al. 1999). Burrow openings are the easier activity indicators, but they are poorly related to abundance (Fig. 1). As far as they persist for several months in arid habitats they cannot be recommended to be used for the estimation of abundance. Therefore relatively fresh indices should be used to detect a presence and thus, to estimate the current relative abundance of $P$. obesus. With regard to such indices, "chenopods", "faeces" and "platforms" correlated well with abundance of $P$. obesus, while "urine" did not. In temperate countries, "faeces" and "fresh diggings" (called tumulus) are also good indicators for measuring abundance of herbivorous rodents as $M$. arvalis (Delattre et al. 1990) and A. terrestris (Giraudoux et al. 1995) respectively. In our study, urine marks are thought to be territorial markers in this species; urine rapidly turns black and forms conspicuous patches around the burrow. These patches last many weeks in dry weather and it is not possible to distinguish fresh patches. Their presence or absence is very dependent on weather conditions, which is one reason why the combined index is so powerful in wet conditions.

The vegetation and faeces indicators, alone or in combination with platforms, are more closely correlated with abundance in wet conditions. When it is dry and hot, food is taken directly into the burrow to be eaten. When burrows were dug out in June, they were found to contain clumps of fresh food, collected at dawn and dusk, so that the animals could shelter from the worst of the heat. Failure of the 1996 autumn rains caused the food-plants to dry out in January 1997 so that, although the abundance of rodents remained high, no remains were seen at the 
burrow entrances. We concluded that the correlation of indicators with abundance was more dependent on weather conditions than on season.

\section{Prospect for use in eco-epidemiology}

This method has the potential use of monitoring fat sand rat populations at a regional scale. For instance, seasonal transects crossing different habitat types in a landscape are very easy to carry out yearly and should permit to estimate the fluctuations of population densities. In Algeria, Amirat et al. $(1975,1977)$ observed most gestation in October and in February/March, which led to increased population in winter, with a fall in summer. Our results show that autumn and spring are the optimal seasons since they cover key periods in the life history of the rodent: the start and the end of the breeding season (Fichet-Calvet et al. 1999). The weather conditions varying at each autumn in Tunisia (wet in 1995 vs dry in 1996), we suggest to use the more general approach based on 2 indices: chenopod remains and faeces, to estimate the relative abundance of $P$. obesus.

A multiannual monitoring of populations at the regional scale is necessary to design a warning system aimed at forecasting outbreaks of the fat sand rat, the main reservoir for Leishmania major. Outbreaks of the disease in man seem to be linked to fluctuations in the numbers of this rodent but this has not been formally established. Only Mbarki et al. (1995) suggest that a high density of $P$. obesus occured before an epidemic of human disease in 1985 in Tunisia. None of the studies clearly demonstrates a correlation between incidence of the human disease and abundance in rodent populations. This simple method for estimating relative abundance could allow for regional studies on the interactions between fat sand rat population densities and infection risks to humans, and for the development of control programmes.

Acknowledgement: This study forms part of a project on the ecological interaction between $P$. obesus and cutaneous leishmaniasis, funded by the Avicenne Programme of the European Commission. The health authorities of Sidi Bouzid provided valuable assistance. We are grateful to R. Ben Ismail, B. P. Kotler, M. Kam and two anonymous referees for the constructive comments on the manuscript. This is a contribution of the Institute of Evolution of Montpellier (No 99-076).

\section{References}

Amirat Z., Khammar F. and Brudieux R. 1975. Variations pondérales saisonnières de l'appareil reproducteur de la surrénale et du rein chez le rat des sables (Psammomys obesus) du Sahara occidental Algérien. Bulletin de la Société d'Histoire naturelle d'Afrique du Nord. Alger 66: 31-60.

Amirat Z., Khammar F. and Brudieux R. 1977. Variations saisonnières comparées de l'activité sexuelle (données pondérales) chez deux espèces de Rongeurs (Psammomys obesus et Gerbillus gerbillus) du Sahara occidental algérien. Mammalia 41: 341-356.

Ashford W. R., Schnur L. F., Chance M. L., Samaan S. A. and Ahmed H. N. 1977. Cutaneous leishmaniasis in the Libyan Arab Republic: preliminary ecological findings. Annals of Tropical Medicine and Parasitology 71: 265-272.

Ben Ismail R., Ben Rachid M. S., Gradoni L., Gramiccia M., Helal H. and Bach-Hamba D. 1987. La Leishmaniose cutanée zoonotique en Tunisie: étude du réservoir dans le foyer de Douara. Annales de la Société Belge de Médecine Tropicale 67: 335-343. 
Ben Ismail R., Khaled S., Makni S. and Ben Rachid M. S. 1989. Anti-leishmanial antibodies during natural infection of Psammomys obesus and Meriones shawi (Rodentia Gerbillinoe) by Leishmania major. Annales de la Société Belge de Médecine Tropicale 69: 35-40.

Daly M. and Daly S. 1975. Behavior of Psammomys obesus (Rodentia : Gerbillinoe) in the Algerian Sahara. Zeitschrift für Tierpsychologie 37: 298-321.

Delattre P., Giraudoux P., Baudry J., Quéré J. P. and Fichet E. 1996. Effect of landscape structure on common vole (Microtus arvalis) distribution and abundance at several scales. Landscape Ecology 11: 279-288.

Delattre P., Giraudoux P., Baudry J., Truchetet D., Musard P., Toussaint M., Stahl P. Poule M. L., Artois M., Damange J. P. and Quéré J. P. 1992. Land use patterns and types of common vole (Microtus arvalis) population kinetics. Agriculture, Ecosystem and Environment 39: 153-169.

Delattre P., Giraudoux P., Damange J. P. and Quéré J. P. 1990. Recherche d'un indicateur de la cinétique démographique des populations du Campagnol des champs (Microtus arvalis). Revue d'Ecologie (Terre et la Vie) 45: 375-384.

Fichet-Calvet E., Jomâa I., Ben Ismail R. and Ashford R. W. 1999. Reproduction and abundance of the fat sand rat (Psammomys obesus) in relation to weather conditions in Tunisia. Journal of Zoology, London 248: 15-26.

Giraudoux P., Delattre P., Habert M., Quéré J. P., Deblay S., Defaut R., Duhamel R., Moissenet M. F., Salvi D. and Truchetet D. 1997. Population dynamics of fossorial water vole (Arvicola terrestris scherman): a land use and landscape perspective. Agriculture, Ecosystem and Environment 66: 47-60.

Giraudoux P., Pradier B., Delattre P., Deblay S. and Defaut R. 1995. Estimation of water vole abundance by using surface indices. Acta Theriologica 40: 77-96.

Kam M. and Degen A. A. 1989. Efficiency of use of Saltbush (Atriplex halimus) for growth by fat sand rats (Psammomys obesus). Journal of Mammalogy 70: 485-493.

Le Houerou H. N. and Le Floc'h E. 1995. La végétation potentielle de la Tunisie aride et désertique (Notice détaillées de la carte au 1/1 000 000). [In: Essai de synthèse sur la végétation et la phyto-écologie tunisiennes. M. A. Nabli, ed]. Programme Flore et Végétation Tunisiennes, Faculté des Sciences Tunis: $389-428$.

Lidicker W. Z. 1995. The landscape concept: something old, something new. [In: Landscape approaches in mammalian ecology and conservation. W. Z. Lidicker, ed]. University Minnesota Press, Minneapolis: 3-19.

Lidicker W. Z. and Anderson P. K. 1962. Colonization of an island by Microtus californicus, analized on the basis of runway transects. Journal of Animal Ecology 31: 503-517.

Liro A. 1974. Renewal of burrow by the common vole as the indicator of its number. Acta Theriologica 19: 259-272.

Mackin-Rogalska R., Adamczewska-Andrzejewska K. and Nabagło L. 1986. Common vole numbers in relation to the utilization of burrow systems. Acta Theriologica 31: 17-44.

Mbarki L., Ben Salah A., Chlif S., Chaded M. K., Balma A., Chemem N., Garraoui A. and Ben Ismail R. 1995. Monitoring zoonotic cutaneous leishmaniasis with GIS. [In: GIS for health and environment. Don de Savigny and P. Wijeyaratne, eds]. IDRC-Ottawa Publications, Ottawa: 115-126.

Ozenda P. 1991. Flore et végétation du Sahara. Centre National de la Recherche Scientifique eds, Paris: 1-662.

Petter F. 1961. Répartition géographique et écologie des Rongeurs désertiques (du Sahara occidental à l'Iran oriental). Mammalia 25: 1-222.

Rioux J.-A., Ashford R. W. and Khiami A. 1992. Ecoepidemiology of leishmaniasis in Syria. 3. Leishmania major infection in Psammomys obesus provides clues to life history of the rodent and possible control measures. Annales de Parasitologie Humaine et Comparée 67: 163-165.

Rioux J.-A., Dereure J., Khiami A., Pratlong F., Sirdar K. and Lambert M. 1990. Ecoépidémiologie des Leishmanioses en Syrie. 1. Infestation de Psammomys obesus Cretzschmar (Rodentia-Gerbillidae) par Leischmania major Yakimoff et Schokhor (Kinetoplastida-Trypanosomatidae). Annales de Parasitologie Humaine et Comparée 65: 203-207. 
Steen H., Ims R. A. and Sonerud G. A. 1996. Spatial and temporal patterns of small rodent population dynamics at a regional scale. Ecology 77: 2365-2372.

Teivanen T. 1979. Vole damage to forest seedlings in reforested areas and fields in Finland in the years 1973-76. Folia Forestalia 387: 1-23.

Wang X. 1993. Analyse du système Campagnol provençal (Microtus - Terricola - duodecimcostatus) à trois niveaux de perception (groupe social, population et métapopulation). $\mathrm{Ph} \mathrm{D}$ thesis, Montpellier II University, Montpellier: 1-166.

Zaime A. and Gautier J.-Y. 1989. Comparaison des régimes alimentaires de trois espèces sympatriques de Gerbillidae en mileu saharien, au Maroc. Revue d'Ecologie (Terre et la Vie) 44: 153-163.

Received 29 November 1997, revised 16 July 1999, accepted 16 August 1999. 